\title{
FAKTOR-FAKTOR YANG MENDASARI STRES PADA LANSIA
}

\author{
Syahnur Rahman \\ syahnur_rahman@gmail.com \\ Departemen Psikologi FIP \\ Universitas Pendidikan Indonesia
}

\begin{abstract}
Humans evolved from helplessness to become a perfect man and independently, and eventually became frail helpless again. However, there are some people who are afraid and do not want to accept reality and do not know what to do facing a period of advanced age. Almost all the events can be a stressor, but some of them further accelerate the onset of stress than others, such as the actions that can cause a person to experience trauma (rape, fires, fight furiously, and others) further accelerate the onset of severe stress rather than natural disasters.
\end{abstract}

Keywords: stress and stress in the elderly

\begin{abstract}
ABSTRAK
Manusia berkembang dari ketidakberdayaan hingga menjadi manusia yang sempurna dan mandiri, dan akhirnya menjadi renta tak berdaya lagi. Akan tetapi, ada sebagian orang yang takut dan tidak mau menerima kenyataannya serta tak tahu harus bagaimana menghadapi masa lanjut usianya. Hampir semua peristiwa dapat menjadi stressor, namun beberapa diantaranya lebih mempercepat timbulnya stres dibandingkan dengan yang lain, seperti tindakantindakan yang dapat menyebabkan seseorang mengalami trauma (perkosaan, kebakaran, pertarungan mati-matian, dan lain-lain) lebih mempercepat timbulnya stres yang berat daripada bencana alam.
\end{abstract}

Kata kunci: stres dan stres pada lansia

\section{PENDAHULUAN}

Manusia berkembang dari ketidak-berdayaan hingga menjadi manusia yang sempurna dan mandiri, dan akhirnya menjadi renta tak berdaya lagi. Akan tetapi, ada sebagian orang yang takut dan tidak mau menerima kenyataannya serta tak tahu harus bagaimana menghadapi masa lanjut usianya. Bila seseorang yang sudah beranjak jauh dari periode hidupnya yang terdahulu, ia sering melihat masa lalunya biasanya penuh penyesalan dan cenderung ingin hidup pada masa sekarang, mencoba mengabaikan masa depan sedapat mungkin.

Usia enam puluh biasanya dipandang sebagai garis pemisah antara usia madya dan usia lanjut. Akan tetapi orang sering menyadari bahwa usia kronologis merupakan criteria yang kurang baik dalam menandai permulaan usia lanjut karena terdapat perbedaan tertentu di antara individu-individu dalam usia pada saat mana usia lanjut mereka mulai.

Manusia berkembang dari ketidakberdayaan hingga menjadi manusia yang sempurna dan mandiri, dan akhirnya menjadi renta tak berdaya lagi. Akan tetapi, ada sebagian orang yang takut dan tidak mau menerima kenyataannya serta tak tahu harus bagaimana menghadapi masa lanjut usianya. Betapa banyak orang lanjut usia yang merasa kesepian dan tak berguna, dan tak sedikit pula yang mengalami stres.

Setiap orang kadang-kadang mengalami stres, karena merasa terus menerus ditekan untuk mencapai lebih banyak hal dalam waktu yang semakin menipis dan sedikit. Pemaparan tentang stres erat kaitannya dengan emosi yang menyakitkan (Atkinson, 1990).

Menurut para peneliti dan ahli psikologi, stres pada zaman modern ini lebih disebabkan karena banyaknya perubahan yang harus dihadapi, menuntut adaptasi dan penyesuaian 
yang pesat, tentunya tidak mudah untuk dicapai dan dilaksanakan oleh semua orang dengan sama mudahnya, sehingga tidak menutup kemungkinan berkembang menjadi stres ( Gunarsa, 2011).

Hammer dan Organ (Frasser, 1985) mengatakan bahwa stres sebagai suatu keadaan seseorang tidak mampu memberi respon yang tepat dan wajar terhadap rangsangan yang datang dari lingkungannya atau mungkin mampu tetapi dengan akibat merugikan.

Begitu pula pada orang usia lanjut. Tak jarang dari mereka merasakan stres karena berbagai masalah dan peristiwa yang muncul dalam kehidupan sehari-harinya. Salah satunya adalah masalah tempat dimana mereka tinggal. Pada sebagian lansia memilih untuk tinggal bersama keluarganya. Mereka merasa kuatir atau takut jika tinggal sendirian dan jika terjadi hal-hal buruk yang akan menimpa dirinya, tak ada seorangpun yang akan menolongnya.

Manusia dalam kehidupan senantiasa membutuhkan kehadiran orang lain, untuk dapat memenuhi kebutuhan baik secara fisik maupun psikis. Sejak lahir manusia adalah makhluk penerima, ia pun tidak bisa mengetahui apa-apa, kecuali rasa aman dan nyaman, kehangatan dan kemesraan sehingga berangsur-angsur individu memahami isyarat ekspresi manusia yang ada di sekelilingnya. Kehadiran orang lain ini akan mampu membawa dan meningkatkan rasa aman bagi individu khususnya ketika menghadapi ketidakpastian dan ancaman dari luar.

\section{Definisi Stres}

Stres telah menjadi topik yang sangat popular untuk dibahas, baik di buku, di majalah, maupun di media elektronik seperti televisi dan radio. Media seringkali menyatakan perilaku atau penyakit yang tidak lazim pada manusia sebagai akibat dari stres. Stres sudah merupakan suatu bagian dari hidup manusia yang tidak dapat dihindari. Ketika seseorang lahir, orang tersebut menghadapi banyak tuntutan dan tantangan baik dari dirinya sendiri maupun lingkungan, seperti makanan, air, ataupun penghargaan dan penerimaan sosial. Agar dapat terus hidup dan berkembang, seseorang harus memenuhi tuntutan dan tantangan tersebut.

Banyak ahli telah melakukan penelitian tentang stres dan mengemukakan berbagai pengertian tentang stres. Diantaranya oleh Atwater (1987) yang menyatakan stres sebagai stimulus eksternal yang menyebabkan seseorang merasa letih, seperti tekanan di tempat kerja, namun pada saat yang sama stimulus tersebut dapat menyebabkan dua orang yang berbeda memberikan respon yang berbeda pula. Cara seseorang merespon stimulus akan menentukan tingkat stress yang dialami.

Stres adalah reaksi fisiologis dan psikologis yang terjadi jika seseorang merasakan ketidakseimbangan antara tuntutan yang dihadapi dengan kemampuan untuk mengatasi tuntutan tersebut. (CranwellWard, 1990).

Menurut Kamus Lengkap Psikologi, stres adalah suatu keadaan tertekan baik secara fisik maupun secara psikologis; dan memberikan tekanan dan ketegasan dalam bicara ataupun tulisan (Chaplin, 1997). Stres dapat dikatakan adalah gejala penyakit masa kini yang erat kaitannya dengan adanya kemajuan pesat dan perubahan yang menuntut adaptasi seseorang terhadap perubahan tersebut dengan sama pesatnya. Usaha, kesulitan, hambatan, dan kegagalan dalam mengikuti derap kemajuan dan perubahannya menimbulkan beraneka ragam keluhan. (Gunarsa, 2001).

Pada dasarnya menurut Fraser (1985) stress disebabkan kombinasi dari lingkungan eksternal dan faktor psikologis. Artinya pada saat individu merasakan bahwa ia dapat berhadapan dengan stressor, secara adaptif kondisi mental atau fisik akan berubah untuk menyesuaikan dengan stimulus tersebut (stressor) yang disebut stres. Masing-masing individu mempunyai tingkat toleransi terhadap stres. Bahkan jika tidak ada stressor 
eksternal, individu mungkin menciptakan stressornya sendiri. Fenomena stres sangat individualistik sifatnya.

Korchin (dalam Atkinson, 1990) mengatakan keadaan stres timbul apabila ada tuntutan yang luar biasa, sehingga mengancam kesejahteraan atau integritas seseorang. Stres tidak hanya berupa kondisi yang menekan seseorang atau keadaan fisik atau psikis seseorang, maupun reaksireaksinya terhadap tekanan itu, melainkan keterkaitan antara ketiga hal tersebut.

Dari berbagai pengertian-pengertian diatas dapat disimpulkan bahwa stress merupakan suatu pola reaksi yang ditunjukkan seseorang saat orang tersebut menghadapi satu atau lebih stimulus dari luar dirinya, yang dianggap sebagai ancaman, tantangan ataupun bahaya terhadap kesejahteraan, harga diri, maupun integritasnya. Pola reaksi yang ditunjukkan meliputi pola reaksi secara fisik seperti timbulnya rasa cemas. Akibat timbulnya pola-pola reaksi ini, keseimbangan tubuh terganggu, dan dapat menyebabkan seseorang merasa lelah sehingga di perlukan energy yang besar untuk memulihkan keseimbangan tubuhnya.

\section{Faktor-faktor yang menyebabkan stres}

Penilaian peristiwa sebagai stressfull tergantung pada dua tipe, yaitu yang berhubungan dengan individu, dan yang berhubungan dengan situasi (Cohen \& Lazarus, Lazarus \& Folkman, dalam Sarafino, 1990). Faktor individu, khususnya faktor kepribadian dapat mempengaruhi penilaian terhadap stres. Faktor-faktor tersebut mencakup inteletual, motivasi, dan karakteristik kepribadian. Satu contoh yang berkaitan dengan self esteem, yaitu bila seseorang mempunyai kepercayaan diri tinggi akan yakin bahwa mereka mempunyai sumber-sumber daya untuk menghadapi tuntutan yang memerlukan kekuatan yang mereka miliki. Jika mereka merasa suatu peristiwa sebagai stressfull, mereka akan menginterpretasikannya sebagai tantangan daripada suatu ancaman. Contoh lain berkaitan dengan motivasi, semakin penting suatu tujuan mengancam, semakin lebih stres seseorang akan merasakannya. Jika yang berkaitan dengan keyakinan seseorang irasional, yang akan menambah stres karena hampir segala kesalahan atau ketidakenakan akan dinilai sebagai membahayakan atau mengancam (Ellis, dalam Sarafino, 1990).

Stres juga tidak hanya terjadi karena peristiwa-peristiwa (stressor) yang bersifat negative, tetapi stres dapat juga disebabkan oleh peristiwa-peristiwa (stressor) yang bersifat positif, seperti pernikahan, atau kombinasi dari peristiwa-peristiwa negatif dan positif (Zimbardo, 1985).

Stres terjadi saat seseorang menilai satu atau beberapa stimulus yang diterimanya dari kehidupan sehari-hari sebagai bahaya, ancaman, atau tantangan. Stimulus-stimulus yang dapat menyebabkan stres tersebut baik yang bersifat eksternal maupun internal, disebut stressor. Hampir semua peristiwa dapat menjadi stressor, namun beberapa diantaranya lebih mempercepat timbulnya stres dibandingkan dengan yang lain, seperti tindakan-tindakan yang dapat menyebabkan seseorang mengalami trauma (perkosaan, kebakaran, pertarungan mati-matian, dan lain-lain) lebih mempercepat timbulnya stres yang berat daripada bencana alam (Atwater, 1987).

Lebih lanjut dikemukakan oleh Paterson dan Neufeld (dalam Feldman, 1989) bahwa stressor yang berbeda masing-masing individu, dapat berubah menjadi bukan stressor pada individu yang sama namun pada saat yang berbeda. Misalnya, seseorang anak menganggap nilai ujian matematika yang jelek sebagai stressor, tetapi saat sebagian besar teman sekelasnya mendapat nilai jelek bukan stressor lagi bagi anak tersebut.

Berdasarkan ulasan diatas tampak bahwa stressor adalah stimulus-stimulus, baik yang bersifat eksternal maupun internal, yang dapat menyebabkan seseorang mengalami stres hampir semua peristiwa dalam hidup 
ini dapat menjadi stressor, namun masingmasing individu memiliki stressor yang berbeda. Sebuah peristiwa dapat dianggap stressor oleh seorang individu, sementara individu lain menganggap persitiwa tersebut bukan stressor. Bahkan sebuah peristiwa yang semula dianggap stressor oleh seorang individu, pada saat yang berbeda dapat dianggap bukan stressor lagi.

\section{Sumber-sumber stres}

Bayi, anak-anak, dewasa, dan lanjut usia, semua mengalami stres. Sumber-sumber stres dapat berubah seperti perkembangan manusia, tetapi kondisi stres dapat terjadi setiap waktu sepanjang hidup. Darimanakah datangnya stres? Apakah sumber-sumbernya? Berikut ini akan dijelaskan sumber-sumber yang timbul di dalam diri individu, dalam keluarga, dalam komunitas dan masyarakat.

\section{a) Sumber-sumber di dalam individu}

Satu cara stres muncul di dalam individu adalah melalui rasa sakit. Sakit menempatkan tuntutan pada system biologik, psikologik seseorang, dan derajat stres. Tuntutantuntutan ini menghasilkan ketergantungan pada keseriusan rasa sakit, dan antara lain juga umur individu. Mengapa umur individu penting? Satu hal, kemampuan tubuh untuk melawan penyakit pada masa anak-anak adalah tinggi, dan menurun pada usia tua. Alasan lain adalah arti dari keseriusan rasa sakit bagi individu, berubah umur. Contohnya, anak muda mempunyai pengertian yang terbatas mengenai penyakit dan kematian. Penilaian mereka terhadap stres yang muncul dari rasa sakit mereka terfokus pada saat ini, daripada memperhatikam masa depan; seperti mereka merasa kegiatan mereka terganggu. Penilaian stres melalui rasa sakit orang dewasa secara khas menyangkut kesulitan sekarang dan memperhatikan masa depan; seperti kemungkinan lumpuh atau mati.

Cara lain stres muncul di dalam individu adalah melalui penilaian kekuatan motivasi yang berlawanan, ketika suatu keadaan konflik muncul. Konflik yang mendorong dan menarik menghasilkan dua kecenderungan yang berlawanan, yaitu mendekat dan menjauh. Dalam hal ini semakin penting individu menerima keputusannya, semakin besar stres yang ditimbulkan. Demikian juga umumnya orang mengalami kesulitan untuk memecahkan konflik menjauh dan sangat menegangkan.

\section{b) Sumber-sumber konflik di dalam keluarga}

Perilaku kebutuhan dan kepribadian tiap anggota keluarga mempengaruhi interaksi diantara anggota keluarga, kadang-kadang menimbulkan stres. Konflik interpersonal dapat muncul dari masalah keuangan, dari perilaku yang tidak dapat diperhatikan, atau dari tujuan yang bertentangan. Ini dapat dilihat dari berebut program TV diantara saudara, atau orang tua menghadapi anak-anak yang memainkan musik dengan keras. Hidup dalam rumah tangga yang terlalu ramai, menambah konflik secara pribadi dan penggunaan sumber-sumber keluarga. Disamping itu peristiwa yang dapat menimbulkan konflik di dalam keluarga adalah penambahan anggota keluarga, keadaan sakit, ketidakmampuan, dan kematian dalam keluarga.

\section{c) Sumber di dalam komunitas dan masyarakat}

Hubungan dengan orang lain yang dilakukan seseorang diluar keluarganya, menyediakan banyak sumber stres. Misalnya anak-anak mengalami stres di sekolah, dalam peristiwa persaingan seperti olahraga atau prestasi (Passer, dalam Sarafino, 1990). Pengalaman stres orang dewasa banyak berhubungan dengan pekerjaan mereka dan situasi lingkungan yang beragam dapat menjadi stressfull. Bagi beberapa individu situasi stresfull hanya sedikit, singkat dan kurang berpengaruh, namun bagi individu lain, stres tersebut kuat dan berlangsung 
lama.

\section{LANSIA (LANJUT USIA) Definisi Lansia}

Masa tua akan datang dengan sendirinya tanpa diminta, dimana tidak semua orang bisa menerima kenyataan ini dengan lapang dada. Masa tua merupakan proses yang berkelanjutan dalam dimensi waktu dan merupakan fase terakhir dari perkembangan seseorang.

Banyak istilah yang dikenal masyarakat untuk menyebut orang lanjut usia, antara lain lansia yang merupakan singkatan dari lanjut usia. Istilah lain adalah manula yang merupakan singkatan dari manusia lanjut usia, dalam bidang ilmu kesehatan masyarakat ada istilah usila singkatan dari usia lanjut.

Pada waktu seseorang memasuki masa usia lanjut, terjadi berbagai perubahan fisik, psikologis, maupun sosial. Perubahan yang bersifat fisik antara lain berupa stamina dan penampilan. Hal ini dapat menyebabkan beberapa orang menjadi depresif dalam pekerjaan dan peran sosial jika mereka tergantung pada energy fisik yang sekarang tidak dimiliki lagi. Sebaliknya, mereka harus lebih menekankan kemampuan berpikir dari kemampuan fisik untuk memecahkan masalah. Jadi yang terpenting bagi lanjut usia adalah bagaimana mengalihkan kemampuan fisik ke dalam kemampuan mental atau kemampuan kebijakan dalam berperilaku (Peck dalam Neugarten, 1968).

Hurlock (1992) juga menjelaskan dua perubahan lain yang harus dihadapi oleh individu lanjut usia, yaitu perubahan sosial dan perubahan ekonomi. Perubahan sosial yang terjadi pada individu lanjut usia meliputi kematian pasangan hidupnya atau temantemannya; perubahan peran dari seorang ayah atau ibu menjadi seorang kakek atau nenek; perubahan dalam hubungannya dengan anakanak karena sudah harus memperhatikan dari tingkatan anak sebagai individu dewasa yang dapat dianggap sebagai teman untuk diminta pendapat dan pertolongan, sebagai contoh perubahan peran dari seorang pekerja menjadi pensiunan yang sebagian besar waktunya dihabiskan dirumah. Perubahan ekonomi berkaitan dengan status sosial dan prestise dalam masyarakat sebagai seorang pensiunan; perubahan pendapatan karena hidupnya tergantung dari tunjangan pensiun. Kondisi-kondisi khas yang serupa dengan penurunan kemampuan ini akan memunculkan gejala umum pada individu lanjut usia yaitu perasaan takut menjadi tua sepanjang tidak dipersiapkan dengan baik dan matang.

Dengan demikian, perubahan sosial yang terjadi pada masa usia lanjut walaupun mengalami penurunan, tetapi hal ini terjadi secara bergantian. Seperti adanya aktivitas yang menurun, yang berhubungan dengan kemampuan fisik dapat diganti dengan aktivitas yang baru tidak tergantung dengan menggunakan energi fisik. Hilangnya peranperan sosial dapat diganti dengan peran-peran baru. Demikian juga, partisipasi sosial yang menurun dapat diganti dengan meningkatkan partisipasi dalam bidang yang berbeda.

\section{Batasan Masa Usia Lanjut}

Masa usia lanjut merupakan tahapan paling akhir dalam perjalanan hidup manusia. Proses menua tersebut selain merupakan proses perkembangan yang terus berlangsung hingga akhir hidup manusia, juga ditandai dengan adanya kemunduran secara fisik dan psikis.

Batasan mengenai masa usia lanjut belum mendapatkan kesepakatan yang pasti (Hurlock, 1980) menyatakan bahwa masa lanjut usia terdiri dari masa usia lanjut awal yang berkisar antara 60 tahun sampai 70 tahun dan masa usia lanjut ditandai dengan dari usia 70 tahun sampai akhir kehidupan seseorang. (Rogers, 1979) menjabarkan bahwa masa usia lanjut ditujukan sebagai orang yang sudah mulai meninggalkan pekerjaan untuk istirahat. (Haditono, 1989) menyatakan bahwa rentang usia 65 tahun keatas adalah termasuk dalam masa usia 
lanjut. Lebih lanjut (Monks dkk, 1998) menunjukkan bahwa masa usia lanjut (Old Age) mulai usia 65 hingga meninggal dunia. (Depsos. RI, 2003) dalam pola Pembangunan Kesejahteraan Sosial bahwa lanjut usia mulai dari usia 60 tahun sampai meninggal dunia.

\section{Perubahan-perubahan yang Terjadi pada Usia Lanjut}

a. Perubahan fisik

Sebagian besar perubahan fisik pada usia lanjut terjadi kearah yang memburuk, proses dan kecepatannya sangat berbeda untuk masing-masing individu. Perubahan fisik pada lansia ini meliputi: perubahan penampilan, perubahan bagian dalam tubuh, perubahan fungsi fisiologi, panca indra dan perubahan seksual.

b. Perubahan kemampuan motorik

Usia lanjut pada umumnya mereka menjadi lebih lambat dan koordinasi gerakan kurang begitu baik dibanding dengan masa mudanya. Perubahan ini disebabkan oleh pengaruh fisik dan psikologis seperti berikut ini: (a) Penyebab fisik yang mempengaruhi perubahan dalam kemampuan motorik meliputi menurunnya kekuatan dan tenaga yang terjadi karena bertambahnya usia, menurunnya kekuatan otot, kekakuan dalam persendian, gemetar pada tangan; (b) Penyebab psikologis berasaldarikesadarantentangmerosotnya dan perasaan akan rendah diri kalau dibandingkan dengan orang yang lebih muda dalam arti kekuatan, kecepatan dan keterampilan; (c) Perubahan kemampuan mental. Dari hasil studi para psikolog telah memperkuat kepercayaan dalam masyarakat, bahwa kecenderungan tentang menurunnya berbagai hal secara otomatis akan menimbulkan kemunduran kemampuan mental; dan (d) Perubahan minat pada usia lanjut.

Terdapat hubungan yang erat antara jumlah keinginan dan minat seseorang pada seluruh tingkat usia dan keberhasilan penyesuaian mereka. Perubahan minat dan keinginan ini harus dilakukan baik secara suka rela atau terpaksa karena alasan kesehatan, situasi keuangan, atau alasan lainnya untuk memperoleh kepuasan yang lebih baik (Hurlock, 1999).

\section{SIMPULAN}

Salah satu faktor lain yang mempengaruhi stres adalah bagaimana lansia itu senidri dalam mememasuki masa tuanya. Bagi mereka yang telah mempersiapkan dirinya sedini mungkin untuk memasuki masa tua, membuat ia lebih mengerti dan memeahami serta dapat menerima segala perubahan dan keterbatasan yang mendadak muncul pada masa lanjut usia.

\section{DAFTAR RUJUKAN}

Atkinson, J.M. 1990. Mengenal Stres di Tempat Kerja. Terjemahan Yoesoef Budiman. Jakarta. Binarupa Aksara.

Atwater, E. 1987. Psychology of Adjustment. New Jersey. Prentice-hall Inc.

Chaplin, J.P. 1997. Kamus Lengkap Psikologi. Jakarta; PT Raja Frafido Persada.

Cranwell-Ward, J. 1990. Thriving on Stress. London. Routledge.

Departemen Sosial RI, 2003. Pola Pembangunan Kesejahteraan Sosial. Jakarta.

Feldman, R.S. 1989. Adjustment, Applying Psychology in A Complex World. New York. Mc. Graw-hill Book Company.

Frasser, T.M. 1985. Stres dan Kepuasan Kerja. Jakarta. PT. Pustaka Binaan Presindo.

Gunarsa, S. D. dkk. 2011. Psikologi Praktis: Anak, Remaja dan Keluarga. Jakarta: PT BPK Gunung Mulia. 
Haditono, S. R. 1989. Kebutuhan dan Cinta Diri Orang Lanjut Usia. Laporan Penelitian. Yogyakarta. Lembaga Penelitian Universitas Gadjah Mada.

Hurlock, E. B. 1980. Developmental Psychology. 4th Edition. New Delhi: Tata Mcgraw-Hill Publishing. 1992. Psikologi Perkembangan. Jakarta: Erlangga. 1999. Psikologi Perkembangan. Jakarta: Erlangga.

Monks, F.J., Knoers, A.M.P., \& Haditono, S.R. 1998. Psikologi Perkembangan: Pengantar Dalam Berbagai Perkembangannya. Ed 5. Yogyakarta: Gadjah Mada University Press.

Neugarten, B.L., Havighurst, R.J.., \& Tobin, S.S. 1968. Personality and Patterns og Aging dalam Neugarten, B.L (Ed). Middle Age ang Aging. A Reader in Social Psychology. Chicago: The University Of Chicago Press.

Rogers, D. 1979. The Adult Years, An Introduction To Aging. New Jersey: Prentice-Hall Inc.

Sarafino, EP. 1990. Health Psychology: Biopsychosocial Interaction. New York: John Wiley \& Sons Inc.

Zimbardo, P.G. 1985. Psychology and Life. Scot, Foresman and Company, Illinois. 